\title{
走能力の異なる集団の身体特性 ——般高校生男子—
}

\author{
出 村 慎 一* 松 沢 甚三郎** 塚 谷 敏 勝* \\ PHYSICAL TRAITS OF FOUR GROUPS WITH \\ DIFFERENT RUNNING ABILITIES
}

\section{Shinichi Demura, Jinzaburo Matsuzawa and Toshikatu Tukatani}

\begin{abstract}
As physical elements appear to relate independently to the achievement in each running performance, it may be appropriate to separate the general population into several groups when physical traits specific to the achievement in each running performance are investigated. For this reason, the following four groups were arbitrary set: Group FF with higher running speed in both $100 \mathrm{~m}$ and $10 \mathrm{~km}$ runs, Group SS with slower running speed in both $100 \mathrm{~m}$ and $10 \mathrm{~km}$ runs, Group FS with higher running speed only in $100 \mathrm{~m}$ run, and Group SF with higer running speed only $10 \mathrm{~km}$ run. The purpose of this study was to compare physical elements and their developmental balance between 4 different groups in terms of running ability. The subjects were 166 high school boys aged 15 to 18 ( $\bar{X}=16.9 \mathrm{yr}$ ). Within the limitation of the present study, the folowing conclusions were drawn :

1) Group SS was much inferior to the other groups in many tests representing power, agility, balance, coordination, and leg muscular endurance. This group also possessed higher body fat. And scores in such traits as power and agility were significantly higher in FF group than in SF group.

2) Factor analysis showed that physical fitness domain represented by 30 variables would be divided into six factors. While group SS possessed greater body bulk(F1) than the other groups, it had much inferior ability in power and agility(F5). Cardio-respira. tory function (F4) was significantly better in FF and SF groups as compared with SS and FS groups. However, no distinct differences existed beween groups in any of static strength (F2), body linearity (F3), and flexibility (F6) factors.

3) Finally, this study supports the hypothesis that the developmental balance of physical elements is specific to each running group. Particularly, it is interesting to note that group SS showed higher scres in body bulk and lower scores in cardio-respiratory function, power and agility as compared with scores in the other factors.
\end{abstract}

(J. Physical Fitness Japan 1984, $33: 148 \sim 156$ )

key words : 身体特性, 走能力, 体力プロフィール, 一般高校生

\section{I. 緒}

トレーニングを十分積んだ短距離走選手は, 短 距離走の成就にとくに要求されるパワー，スピー ド, 敏捷性, 等の能力が発達しており, 長距離走 選手は，とくに心肺機能が発達していると考えら れる ${ }^{13)}$ 。また，前述の両選手の場合，体格面にお
いても差異があることが報告されている(6)725!。 一方, 特別にトレーニングを行なっていない一 般の青少年にとって, 走運動は最も基本的な運動 の 1 つであるが，中には距離の差異に関係なく走 能力に優れている者, 劣る者, あるいは短距離走 能力には優れているが長距離走能力には劣る者, またこの逆のケースの者が存在すると考えられ

\footnotetext{
* 仁愛女子短期大学 Jin-ai Women's Junior College, Takefu, Fukui 915

** 福井工業高等専門学校 Fukui Technical College, Sabae, Fukui 916
} 
る。一般に, 走選手の場合には, 短距離あるいは 長距離走のいずれかに特に優れていると考えられ るので，両走能力に劣るあるいは優れる者の存在 は，特に一般集団において見られるものであろ ら。

これら一般の走能力の異なる集団は，それぞれ 独自の身体特性をもち, 短距離及び長距離走選手 のものとも異なることが考えられる。

これ迄，走トレーニングを積んだ選手の身体特 性に関しては, 浅川122), 田中ら ${ }^{28 / 291}$, 田中 ${ }^{25 / 26) 271, ~}$

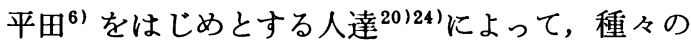
立場から研究されて来た。しかし，前述した一般 の走能力の異なる集団の身体特性に関しては十分 明らかにされているとは言いがたい。

本研究の目的は, 一般高校男子の中から, 走能 力の異なる 4 集団を選出し, この 4 群の身体特性 を明らかにすることであった。

\section{II. 方 法}

\section{1. 標本}

被検者は, 15 18歳の健康な一般高校生男子 166名で，平均年秢は16.9歳であった。

\section{2. テスト項目}

○走能力 : 短距離走能力として $100 \mathrm{~m}$ 走, 韦距離 走能力として $10 \mathrm{~km}$ 走を選択した(表 1 )。 $100 \mathrm{~m}$ 走テストは，第 4 種日本陸連公認陸上競技場を 利用して，10km 走テストは日本陸連公認長距 離競走路に準ずる方法に従って計測されたロー ドレースコースを利用して行なわれた。

。体格：身長, 座高, 体重, 及び上腕背部, 肩甲 骨下部，腹部の 3 皮脂厚を計測した。また，体 脂肪率, 体密度, 除脂肪体重, 体表面積 も Brožek ら ${ }^{31}$ 及び長嶺ら ${ }^{20)}$ の式を利用して算出 した（表 1 )。なお，皮脂厚は栄研式皮脂厚計で 計測した。

。体力 : 静的筋力 (背筋力, 握力), 筋持久力 (懸 垂・スクワットジャンプ・仰臥脚上げ), パワー (垂直跳・走り幅跳・立幅跳・ハンドボール投), 柔軟性（上体反らし・立位体前屈）平衡性（片 足爪先立), 協応性 (ジグザグドリブル), 敏捷性 (サイドステップ・バーピーテスト・50m シャ トルラン), 心肺機能 (ステップテスト・安静時
表 1 平均値及び標準偏差

\begin{tabular}{|c|c|c|c|}
\hline 番号 & 変 & $\overline{\mathrm{X}}$ & SD \\
\hline 1 & $100 \mathrm{~m}$ 走 $(\mathrm{m} / \mathrm{s})$ & 7.0 & 0.46 \\
\hline 2 & $10 \mathrm{~km}$ 走 $(\mathrm{m} / \mathrm{s})$ & 3.3 & 0.40 \\
\hline 1 & 身 長 $(\mathrm{cm})$ & 168.7 & 5.17 \\
\hline 2 & 座 高 $(\mathrm{cm})$ & 91.0 & 3.03 \\
\hline 3 & 胸 囲 $(\mathrm{cm})$ & 84.1 & 5.38 \\
\hline 4 & 体 重(kg) & 59.3 & 9.15 \\
\hline 5 & 皮脂厚：上腕背部 $(\mathrm{mm})$ & 9.6 & 4.20 \\
\hline 6 & 皮脂厚 : 肩甲骨下部 (mm) & 10.3 & 6.34 \\
\hline 7 & 皮脂厚 : 腹部 $(\mathrm{mm})$ & 12.0 & 8.94 \\
\hline 8 & 体脂肪率(\%) & 15.5 & 5.17 \\
\hline 9 & 体密度 & 10.6 & 0.13 \\
\hline 10 & 除脂肪体重(kg) & 50.6 & 5.11 \\
\hline 11 & 体表面積 $\left(\mathrm{m}^{2}\right)$ & 17.1 & 1.21 \\
\hline 12 & 背笳力 $(\mathrm{kg})$ & 133.4 & 27.08 \\
\hline 13 & 握 力 $(\mathrm{kg})$ & 42.1 & 6.51 \\
\hline 14 & 緊 垂(回) & 6.3 & 3.47 \\
\hline 15 & スクワットジ+ンプ(回) & 56.9 & 7.27 \\
\hline 16 & 仰臥脚上げ(秒) & 91.8 & 43.10 \\
\hline 17 & 垂直跳(cm) & 55.7 & 7.78 \\
\hline 18 & 走り幅跳び(cm) & 441.5 & 46.89 \\
\hline 19 & 立幅跳び (cm) & 237.9 & 16.12 \\
\hline 20 & ハンドボール投 $(\mathrm{m})$ & 24.8 & 3.52 \\
\hline 21 & 上体反らし(cm) & 56.2 & 7.07 \\
\hline 22 & 立位体前屈(cm) & 13.1 & 5.79 \\
\hline 23 & 片足爪先立(秒) & 48.2 & 27.90 \\
\hline 24 & ジグザグドリブル(秒) & 20.3 & 1.90 \\
\hline 25 & サイドステップ(回) & 45.5 & 4.11 \\
\hline 26 & バーピーテスト(回) & 7.3 & 0.71 \\
\hline 27 & $50 \mathrm{~m}$ シャトルラン(秒) & 14.8 & 0.88 \\
\hline 28 & ステップテスト(指数) & 69.9 & 12.99 \\
\hline 29 & 安静時心博数(回) & 66.9 & 7.47 \\
\hline 30 & 肺活量 $\left(\mathrm{cm}^{3}\right)$ & $4,082.5$ & 492.54 \\
\hline
\end{tabular}

注：変量11の平均値・標準偏差は $\times 100$

心拍数・肺活量）を代表する19項目を選択し た。

スクワットジャンプは, 両手を後頭部で組み片 滕立姿勢から空中にジャンプし，立てる膝を交代 させてしゃがみ达み，またジャンプするという動 作を連続する。2 分間に出来た回数を測定値とし た。

仰臥脚上げは，両手を後頭部で組み仰臥姿勢を とり，両脚を上げる(踵が床から $15 \mathrm{~cm})$ 。脚上げ 持続時間を測定値とした (最高 3 分)。 
立巾跳は，両足を揃えた立位姿勢から前方に出 来るだけ遠く跳べる距離を測定した。

片足爪先立は，両手を腰にとった直立姿勢か ら，片足を前方に上げさせ，10秒後に支持脚の踵 を上げさせた（最高 2 分間）。

パーピーテストは，直立姿勢から両手を足先の 床上につけてしゃがみ込み，次に両足を後方へ突 き出す (腕立伏せ姿勢), 再び両足を縮めてしゃが み姿勢をとり，起立する。この動作を10秒間に反 復して実施らる回数を測定值とした。

$50 \mathrm{~m}$ シャトルランは, 壁から $5 \mathrm{~m}$ 離れた地点に 線を引き，その間を 5 往復するのに要した時間を 計測した。

安静時心拍数は, 座居姿勢をとらせ, 手首の橈 骨動脈に指を当てがって 1 分間計測した注1)。

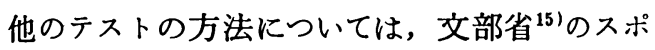
一ツテスト, 壮年体カテストの実施方法に従っ た。

なお，測定は昭和57年 9 月〜 10月の主に体育の 授業時間を利用して行なわれた。

\section{III. 結果}

\section{1. 走能力の異なる集団}

図 1 は, $100 \mathrm{~m}$ 及び $10 \mathrm{~km}$ 走テストに基づき，
両走スピードが $\overline{\mathrm{X}}-0.255 \mathrm{SD}$ 以下に属する者を遅 い群 (S), $\overline{\mathrm{X}}+0.255 \mathrm{SD}$ 以上に属する者を速い群 (F),その中間に属する者を中位群 (M) とし，さ らに, $100 \mathrm{~m}$ 走において, $\mathrm{S}, \mathrm{M}$, 及び $\mathrm{F}$ の各群 に属した者が $10 \mathrm{~km}$ 走の各群にどの程度移行した かを示したものである。

図から, $100 \mathrm{~m}$ 及び $10 \mathrm{~km}$ 走共に遅い群に属 し た者（SS）は32名また，両走共に速い群に属し た者 (FF) は36名でこれは $100 \mathrm{~m}$ 走において 群及び $\mathrm{F}$ 群に属した全体のそれぞれ 49.2\%，58.1 \%に相当する。 $100 \mathrm{~m}$ 走では， S 群に属したが10 $\mathrm{km}$ 走ではF 群に属した者 (SF) は18名, この逆 のケースの者 (FS) は14名でこれは $100 \mathrm{~m}$ 走に 扣いて $\mathrm{S}$ 群及び $\mathrm{F}$ 群に属した全体のそれぞれ 22.6 $\%, 27.7 \%$ に相当する。

表 2 は, 前述の 4 群について, 走能力の差異を 検定したものである。表から，FF 群は短距離及 び長距離の両走能力に優れる集団であり, SS 群は 両走能力に劣る集団であり, SF 群は短距離 走能 力には劣るが長距離走能力には優れる集団であ り, そして FS 群は短距離走能力には優れるが長 距離走能力には劣る集団であると考えられる。ま た, SS 群は SF 群に比べて短距離走能力におい て劣り, FS 群に比べて長距離走能力において劣

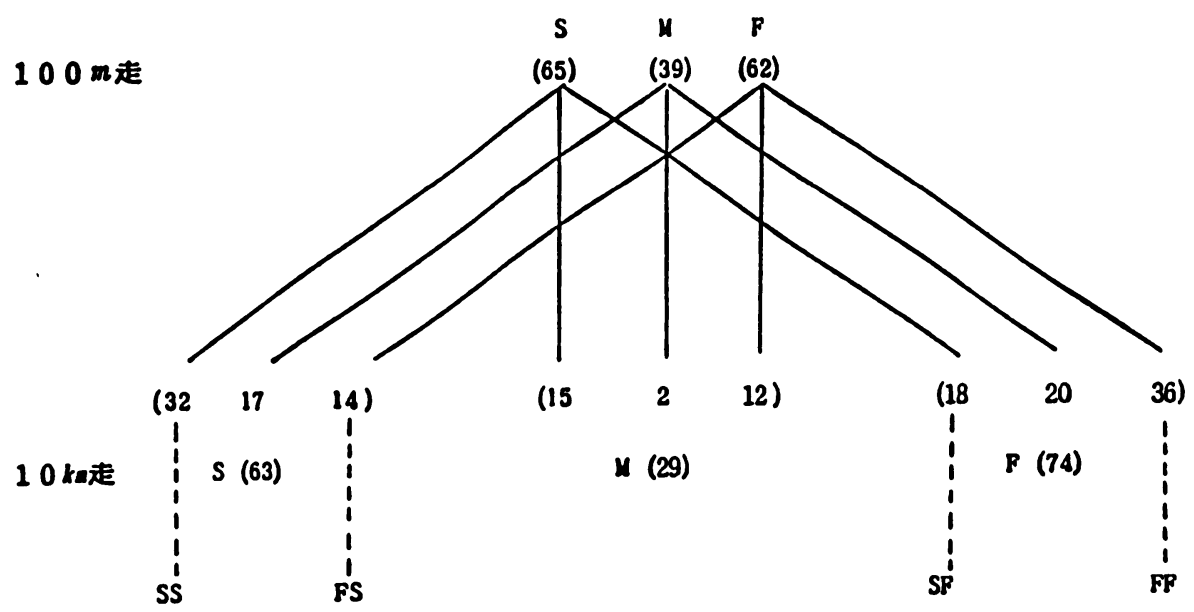

図 1 走能力の異なる 4 集団

注：S：遅い群 $\mathrm{F}$ ：速い群 $\mathrm{M}$ ：中位群 $\mathrm{SS}$ ：両走共飞遅い群 $\mathrm{FF}$ ：両走共に速い群

FS : $100 \mathrm{~m}$ 走は速いが $10 \mathrm{~km}$ 走は遅い群 $\mathrm{SF}: 100 \mathrm{~m}$ 走は遅いが $10 \mathrm{~km}$ 走は速い群

速い群 : $\overline{\mathrm{X}}+0.255 \mathrm{SD}$ 以上飞属する者 遅い群 : $\overline{\mathrm{X}}-0.255 \mathrm{SD}$ 以下に属する者 
表 2 走能力の比較検定絬果

\begin{tabular}{|c|c|c|c|c|c|c|c|c|c|c|}
\hline \multirow[b]{2}{*}{ 走能力 } & \multicolumn{2}{|c|}{ SS } & \multicolumn{2}{|c|}{ SF } & \multicolumn{2}{|c|}{ FS } & \multicolumn{2}{|c|}{ FF } & \multirow[b]{2}{*}{ F一值 } & \multirow[b]{2}{*}{ 多重 比較 } \\
\hline & $\overline{\mathrm{X}}$ & SD & $\overline{\mathrm{X}}$ & SD & $\overline{\mathrm{X}}$ & $\mathrm{SD}$ & $\overline{\mathrm{X}}$ & $\mathrm{SD}$ & & \\
\hline $100 \mathrm{~m}$ & 6.48 & 0.30 & 6.65 & 0.16 & 7.47 & 0.19 & 7.53 & 0.20 & $112.77^{* *}$ & $\mathrm{FF}, \mathrm{FS}>\mathrm{SF}>\mathrm{SS}$ \\
\hline $10 \mathrm{~km}$ & 2.76 & 0.24 & 3.66 & 0.18 & 2.94 & 0.10 & 3.60 & 0.14 & $162.26^{* *}$ & $\mathrm{FF}, \mathrm{SF}>\mathrm{FS}>\mathrm{SS}$ \\
\hline
\end{tabular}

注 : SS, SF, FS, FFの 4 群は図 1 の 4 群名と同じ ${ }^{* *}$ は P $<0.01$

$\mathrm{FF}, \mathrm{FS}>\mathrm{SF}>\mathrm{SS} \mathrm{FF}, \mathrm{FS}$ が $\mathrm{SF}, \mathrm{SS}$ に比べて，SFがSSに比べて有意に勝る( $5 \%$ 水準)

表 3 走能力の異なる 4 群の形態・体力比較

\begin{tabular}{|c|c|c|c|c|c|c|c|c|c|}
\hline \multirow{2}{*}{$\begin{array}{l}\text { 変量 } \\
\text { 号 }\end{array}$} & \multicolumn{2}{|c|}{ SS } & \multicolumn{2}{|c|}{ SF } & \multicolumn{2}{|c|}{ FS } & \multicolumn{2}{|c|}{ FF } & \multirow{2}{*}{ F一值 } \\
\hline & $\overline{\mathrm{X}}$ & $\mathrm{SD}$ & $\overline{\mathbf{X}}$ & SD & $\overline{\mathrm{X}}$ & SD & $\overline{\mathbf{x}}$ & $\mathrm{SD}$ & \\
\hline 1 & 169.8 & 4.87 & 168.9 & 5.42 & 169.3 & 6.50 & 168.1 & 4.72 & 0.592 \\
\hline 2 & 91.4 & 3.00 & 90.2 & 3.09 & 93.0 & 3.47 & 90.7 & 2.73 & 2.562 \\
\hline 3 & 85.9 & 7.57 & 82.0 & 5.42 & 85.3 & 3.02 & 83.9 & 3.76 & 1.926 \\
\hline 4 & 63.8 & 12.16 & 56.8 & 7.67 & 60.9 & 4.75 & 58.2 & 5.20 & $2.926^{*}$ \\
\hline 5 & 13.0 & 6.09 & 8.8 & 2.32 & 9.5 & 2.87 & 8.4 & 2.60 & $4.969 * *$ \\
\hline 6 & 15.8 & 10.84 & 8.3 & 2.26 & 9.6 & 2.29 & 9.1 & 2.49 & $4.682^{* *}$ \\
\hline 7 & 19.5 & 14.95 & 10.0 & 5.44 & 11.4 & 4.52 & 9.6 & 3.95 & $4.345^{* *}$ \\
\hline 8 & 20.6 & 7.58 & 14.1 & 2.36 & 14.9 & 3.16 & 13.7 & 2.41 & $7.476^{* *}$ \\
\hline 9 & 10.5 & 0.18 & 10.7 & 0.06 & 10.7 & 0.08 & 10.7 & 0.07 & $7.416^{* *}$ \\
\hline 10 & 51.3 & 5.38 & 50.4 & 5.31 & 51.8 & 3.95 & 51.1 & 4.27 & 0.217 \\
\hline 11 & 17.8 & 1.51 & 17.0 & 1.12 & 17.2 & 0.86 & 17.0 & 0.86 & 2.372 \\
\hline 12 & 124.8 & 24.15 & 132.4 & 22.22 & 140.8 & 34.60 & 135.1 & 28.56 & 1.340 \\
\hline 13 & 40.8 & 6.40 & 39.9 & 4.86 & 44.0 & 7.28 & 43.9 & 7.09 & 2.312 \\
\hline 14 & 3.8 & 3.19 & 5.7 & 2.16 & 6.9 & 2.67 & 8.5 & 3.75 & $11.910^{* *}$ \\
\hline 15 & 51.0 & 7.72 & 58.2 & 6.26 & 59.6 & 5.17 & 60.3 & 5.72 & $12.655^{* *}$ \\
\hline 16 & 70.7 & 36.07 & 90.2 & 47.37 & 90.0 & 40.35 & 103.0 & 43.84 & $3.269^{*}$ \\
\hline 17 & 49.5 & 7.60 & 53.4 & 5.59 & 61.4 & 9.92 & 58.5 & 5.97 & $12.799^{* *}$ \\
\hline 18 & 392.4 & 38.98 & 434.7 & 27.80 & 467.9 & 49.41 & 475.3 & 30.79 & $31.469^{* *}$ \\
\hline 19 & 224.1 & 15.60 & 235.1 & 11.72 & 243.6 & 14.35 & 247.4 & 13.93 & $15.779^{* *}$ \\
\hline 20 & 23.1 & 3.68 & 23.8 & 2.92 & 26.0 & 3.49 & 25.6 & 3.00 & $4.376^{* *}$ \\
\hline 21 & 54.0 & 8.59 & 54.8 & 7.04 & 58.3 & 5.64 & 56.3 & 6.55 & 1.319 \\
\hline 22 & 11.2 & 6.06 & 13.5 & 3.85 & 12.3 & 10.64 & 13.0 & 4.83 & 1.010 \\
\hline 23 & 29.2 & 13.32 & 47.1 & 25.42 & 47.6 & 27.62 & 57.8 & 27.46 & $11.308^{* *}$ \\
\hline 24 & 21.9 & 2.04 & 20.0 & 1.18 & 20.5 & 1.62 & 19.1 & 1.16 & $16.193^{* *}$ \\
\hline 25 & 42.6 & 3.38 & 44.7 & 4.09 & 46.4 & 4.29 & 47.7 & 3.87 & $10.328^{* *}$ \\
\hline 26 & 6.9 & 0.65 & 7.4 & 0.76 & 7.5 & 0.61 & 7.6 & 0.62 & $6.608^{* *}$ \\
\hline 27 & 15.6 & 1.05 & 14.6 & 0.50 & 14.6 & 0.60 & 14.2 & 0.49 & $15.460^{* *}$ \\
\hline 28 & 64.3 & 12.76 & 74.8 & 11.29 & 64.1 & 10.84 & 71.6 & 13.38 & $3.837^{*}$ \\
\hline 29 & 69.9 & 8.46 & 63.8 & 4.78 & 66.9 & 5.03 & 65.3 & 8.06 & $3.490^{*}$ \\
\hline 30 & $4,024.1$ & 460.01 & $4,065.6$ & 636.71 & $4,163.6$ & 356.05 & 4096.4 & 510.75 & 0.267 \\
\hline
\end{tabular}

注 : 1 30の番号は表 1 の形態・体力変量の番号と同じ

$\mathrm{SS} 100 \mathrm{~m}, 10 \mathrm{~km}$ 共に遅い群，SFは100mは遅いが，10kmは速い群，FSは100mは速いが，10kmは遅い群 FFは $100 \mathrm{~m}, 10 \mathrm{~km}$ 共に速い群 ${ }^{*} \mathrm{P}<0.05{ }^{* *} \mathrm{P}<0.01$ 
ると考えられる。

\section{2. 体格・体力比較}

前述の結果から, SS, SF, FS, 及び FF の 4 群 はそれぞれ走能力の異なる集団と考えられるの で, 本研究ではこの 4 群の体格・体力の比較を行 ならことにした。

表 3 は, 各テスト変量（測定値）について, 前 述の 4 群の差異の検定結果を示したものである。 表 4 は, 一要因分散分析の結果, 有意な差異が認 められた変量について多重比較検定 ${ }^{81}$ (Ryan 法) を行なった結果を示したものである。表 3 から， 体格面では, 身長, 座高, 胸囲, 除脂肪体重, 体 表面積, 体力面では, 背筇力と握力 (静的筋力), 上体反らしと立位体前屈 (柔軟性), 及び肺活量に 有意な差異が認められなかったが，他の全ての項 目に有意な差異が認められた。

表 4 から，体格では，皮脂厚，体脂肪率，及び
体密度は, SS 群と SF, FS, FF の 3 群間に, 体 重は SS 群と SF，FF の 2 群間に有意な差異が認 められた。

体力項目では，スクワットジャンプ，走り幅 跳, 立幅跳, ジグザグドリブル，片足爪先立，バ 一ピーテスト, 及びシャトルランは, SS 群と SF, FS, FF の 3 群間に, そして懸垂, 垂直跳, ハン ドボール投, 及び反復横跳びは, SS 群と FS, FF の 2 群間に有意な差異が認められた。また，ステ ップテスト及び安静時心拍数に関しては, SS 群と $\mathrm{SF}, \mathrm{FF}$ の 2 群間に有意差が認められ, 前者の項 目については FS 群と FF, SF の 2 群間にも有意 差が認められた。

一方, 懸垂，垂直跳，走り幅跳，ジグザグドリ ブル, 及び反復横跳については, FF 群と SF 群 間にも有意な差異が認められた。

表 4 多重比較 検 定結果

\begin{tabular}{|c|c|c|}
\hline 4 & 体 重 & $\mathrm{SS}>\mathrm{SF}, \mathrm{FF}$ \\
\hline 5 & 皮脂厚 : 上腕 & $S S>S F, F S, F F$ \\
\hline 6 & " ：背部 & $\mathrm{SS}>\mathrm{SF}, \mathrm{FS}, \mathrm{FF}$ \\
\hline 7 & "：腹部 & $S S>S F, F S, F F$ \\
\hline 8 & 体脂肪率 & $\mathrm{SS}>\mathrm{SF}, \mathrm{FS}, \mathrm{FF}$ \\
\hline 9 & 体密度 & $\mathrm{SS}<\mathrm{SF}, \mathrm{FS}, \mathrm{FF}$ \\
\hline 14 & 懸 垂 & $\mathrm{SS}<\mathrm{FS}, \mathrm{FF}: \mathrm{SF}<\mathrm{FF}$ \\
\hline 15 & スクワットジャンプ & $\mathrm{SS}<\mathrm{SF}, \mathrm{FS}, \mathrm{FF}$ \\
\hline 16 & 仰臥脚上げ & SS $<$ FF \\
\hline 17 & 垂直跳び & $\mathrm{SS}<\mathrm{FS}, \mathrm{FF}: \mathrm{SF}<\mathrm{FS}, \mathrm{FF}$ \\
\hline 18 & 走り幅跳び & $\mathrm{SS}<\mathrm{SF}, \mathrm{FS}, \mathrm{FF}: \mathrm{SF}<\mathrm{FS}, \mathrm{FF}$ \\
\hline 19 & 立幅跳び & $\mathrm{SS}<\mathrm{SF}, \mathrm{FS}, \mathrm{FF}: \mathrm{SF}<\mathrm{FF}$ \\
\hline 20 & ハンドボール投 & SS $<$ FS, FF \\
\hline 23 & 片足爪先立 & $\mathrm{SS}<\mathrm{SF}, \mathrm{FS}, \mathrm{FF}$ \\
\hline 24 & ジクザクドリブル & $\mathrm{SS}<\mathrm{SF}, \mathrm{FS}, \mathrm{FF}: \mathrm{SF}<\mathrm{FS}, \mathrm{FF}$ \\
\hline 25 & サイドステップ & $\mathrm{SS}<\mathrm{FS}, \mathrm{FF}: \mathrm{SF}<\mathrm{FF}$ \\
\hline 26 & バーピーテスト & $\mathrm{SS}<\mathrm{SF}, \mathrm{FS}, \mathrm{FF}$ \\
\hline 27 & シャトルラン & $\mathrm{SS}<\mathrm{SF}, \mathrm{FS}, \mathrm{FF}$ \\
\hline 28 & ステップテスト & $\mathrm{SS}, \mathrm{FS}<\mathrm{SF}, \mathrm{FF}$ \\
\hline 29 & 心博数 & $\mathrm{SS}>\mathrm{SF}, \mathrm{FF}$ \\
\hline F1 & 量・周育因子 & $S S>S F, F S, F F$ \\
\hline F4 & 心肺機能因子 & $\mathrm{SS}, \mathrm{FS}<\mathrm{SF}, \mathrm{FF}$ \\
\hline F5 & パワー・敏捷性因子 & $\mathrm{SS}<\mathrm{SF}, \mathrm{FS}, \mathrm{FF}: \mathrm{SF}<\mathrm{FF}$ \\
\hline
\end{tabular}

注：番号は表 1 の変量番号と同じ

SS，SF，FS，FFは図 1 及び表 2 のグルーブ名と同じ $\mathrm{SS}<\mathrm{SF}, \mathrm{FF}$ はSF 及び FF 群が SS 群に比べて大 変量24 と27の尺度は变換されている( $5 \%$ 水準) 


\section{3. 体カプロフィール}

表 5 は, 表 1 に示した30変量間の相関行列を求 め, これに因子分析法を適用して得られた因子パ

表 5 因子パターン行列

\begin{tabular}{|c|c|c|c|c|c|c|}
\hline 番号 & $\mathrm{F} 1$ & F2 & F3 & F4 & F5 & $\mathrm{F} 6$ \\
\hline 1 & & & 905 & & & \\
\hline 2 & & & 848 & & & \\
\hline 3 & 767 & & 405 & & & \\
\hline 4 & 762 & & 513 & & & \\
\hline 5 & 881 & & & & & \\
\hline 6 & 885 & & & & & \\
\hline 7 & 897 & & & & & \\
\hline 8 & 919 & & & & & \\
\hline 9 & -909 & & & & & \\
\hline 10 & & & 783 & & & \\
\hline 11 & 619 & & 742 & & & \\
\hline 12 & & 577 & 472 & & & \\
\hline 13 & & 594 & 518 & & & \\
\hline 14 & & 789 & & & & \\
\hline 15 & & 405 & & & 668 & \\
\hline 16 & & 567 & & & & \\
\hline 17 & & & & & 500 & 468 \\
\hline 18 & & & & & 708 & \\
\hline 19 & & & & & 692 & \\
\hline 20 & & & & & 537 & \\
\hline 21 & & & & & & 748 \\
\hline 22 & & 512 & & & & 491 \\
\hline 23 & & & & 498 & & \\
\hline 24 & & & & & -709 & \\
\hline 25 & & & & & 531 & \\
\hline 26 & & & & & 548 & \\
\hline 27 & & & & & -795 & \\
\hline 28 & & & & 760 & & \\
\hline 29 & & & & -755 & & \\
\hline 30 & & & 480 & & & \\
\hline $\mathrm{C}$ & 6.32 & 2.43 & 4.32 & 1.84 & 4.61 & 1.58 \\
\hline$P$ & 21.1 & 8.1 & 14.4 & 6.1 & 15.4 & 5.3 \\
\hline
\end{tabular}

注：0.40以下の負荷量省略, 負荷量の少数点省略 番号は表 1 の形態及び体力の変量番号と同じ C は貢献量 $\mathrm{P}$ 江貢献度

$\mathrm{F} 1$ : 量・周育因子

F3：長育因子

F5：パワー・敏捷性因子
F2: 筋力因子

F4: 心肺機能因子

F6：柔軟性因子
ターン行列を示したものである。抽出された 6 因 子の全分散量に対する貢献度は $70.3 \%$ であったこ とから，30変量によって捉えられる体格・体力領 域の約70\%がこの 6 因子によって説明されると考 えられる。各因子はそれぞれ F1：量・周育, F2： 筋力, F3 : 長育, F4: 心肺機能, F5: パワー・敏 捷性, F6 : 柔軟性因子と解釈されよう。主として 内容妥当性ないし構成妥当性の立場から選択され た表 1 の30变量はそれぞれ前述の 6 能力因子を定 義していると考えられる注2)。

図 2 は, 各群における体力要因の相対的発達程 度を比較するために, 走能力の異なる 4 群につい て平均因子得点注3)を求め, プロットし，体力プロ フィールを描いたものである。表 4 の下部は, 一 要因分散分析の結果, 有意性の認められた因子に ついて多重比較検定を行なった結果を示したもの である。

長育, 柔軟性, 及び静的筋力の 3 因子には有意 な差異が認められなかったが，量・周育は, SS 群 と SF, FS, FF の 3 群間に, 心肺機能は SS 及び FS 群と SF 及び FF 群に, そしてパワー・敏捷 性は, SS 群と SF, FS, FF の 3 群間, 及び SF 群 と FS 群間に有意な差異が認められた。

以上の結果は，前述の测定值を手がかりとして 得られた結果とほぼ一致していると考えられる。

図 2 を体力要素の発達バランス泣4)といら観点 から，4群の体力プロフィールを見ると, SS 群の 場合, 他の要因に比べて, 量・周育は大であるが, パワー・敏捷性は著しく劣り, 心肺機能も劣って いる. FF 群は, 量・周育及び長育の体格面, 柔 軟性に比べて，パワー・敏捷性，心肺機能，ある いは筋力が発達している。 SF 群の場合は, 量・周 育がやや劣り, 心肺機能がやや発達しているが， 全体的に体格・体力要因の調和がとれている。

FS 群は，心肺機能がやや劣るが，長育が大で あり, パワー・敏捷性, 柔軟性が発達していると 考兄られる。

注 2）表 5 の負荷量はいずれる $1 \%$ 水準で有意。従って負荷量を示した変量と因子とは有意な相関がある。

注 3) 完全推定法 ${ }^{18}$ により各因子の推定式を求め, これを利用して各個人の因子得点を算出し，4群の平均因子 得点を求めた。

注 4) 各体力要素相互間の発達関係 


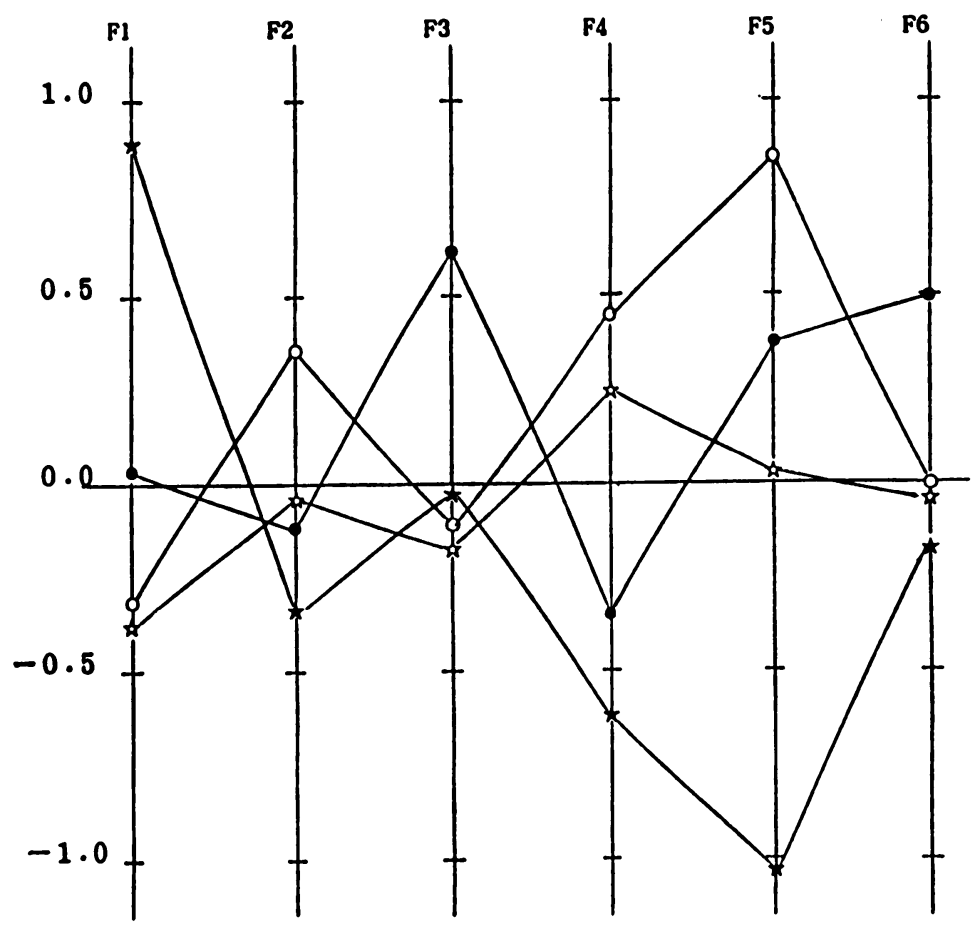

図 2 走能力の異なる 4 集団の体カプロフィール

注 : F1 F6 の因子名は表 4 の因子名と同じ

$\star \mathrm{SS}: 100 \mathrm{~m}, 10 \mathrm{~km}$ 共汇遅い群

OFF : 100m, $10 \mathrm{~km}$ 共飞速い群

\section{IV. 考}

棎

一般に短距離及び長距離トレーニング者の皮脂 厚はらすいと言われている22126)。また，北川ら は, 一般の肥満者の場合, 肥満の影響が持久走な ぞにおいて顕著になると報告している。小野 ${ }^{23)} は$, 一般の中学男子に拈いて，皮脂厚の厚い者ほど持 久走能力に劣ることを考察している。以上の報告 から，走トレーニング者は体脂肪が少なく，ま た，一般人の場合，長距離走能力に劣る者は体脂 肪が多いことが推測される。今回の結果では, SS 群と他の 3 群との体脂肪に有意差が認められた が，FS群と SF 及び FF 群間には有意差が認め られなかった。

従って, 今回の結果から見る限り, 距離の羑異 に関係なく走能力に劣る者は体脂肪が多いが, 長 距離走能力に劣っても短距離走能力に優れる者の 体脂肪は必ずしも多いとは言えないと考えられ る。また, SS 群の場合, 走能力の劣る要因の 1 つとして体脂肪の多いことが影響していると推測
FS : 100m は速いが, $10 \mathrm{~km}$ は遅い群 认SF : 100m は遅いが, $10 \mathrm{~km}$ は速い群
される。

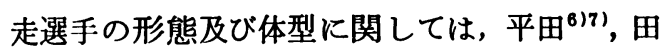
中 $^{28 / 291}$ ，及び，田中 ${ }^{271}$ の報告がある。一般的な特 徵として, 短距離選手は筋肉太りの標準型で, 長 距離選手はやや小柄で度型と言われている25)。

因 2 を量・周育と長育の両体格因子に限定して 考察すると, 長距離走能力に優れる者 (FF 及び $\mathrm{SF}$ 群) は, 両者の発育バランスが比較的とれてい るが, FS 群の場合, 長育が量・周育に比べて大 であり, SS 群の場合は逆に量・周育の方が長 育 に比べて大で，肥満型に近いことが考えられる。

以上のことから, SS 群の体型は走選手には見 られない体型であり，一般の走能力の異なる他の 群とも異なる体型であろらと考えられる。

一方, 小野ら ${ }^{221}$ は, 長期間持久走トレーニング を積んだ高令者の体力分析を行ない，肺活量 1 秒 率及び反復横跳は同年令水準より優れているが， 握力, 垂直跳, 上体反らし, 立位体前屈, 及び静 的筋持久力は必ずしもよくなかったことを報告し ている。これは持久走トレーニング者と一般人と 
の比較であるが，今回の結果では，一般の走能力 の異なる集団間においても, 静的筋力や柔軟性に

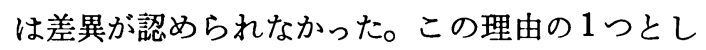
て, 特に一般集団の場合, 静的筋力や柔軟性は走 運動の成就に関与する重要な能力ではないことが 考えられる。

今回の結果から心肺機能に関しては, 長距離走 能力に優れている者 (SF 及び FF) の方が劣る者 (SS 及び FS)に比べて発達しており，また，パワ 一, 敏捷性, 筋持久力に関しては, 長・短距離走 能力に劣る者の方が両走能力に優れる者あるいは いずれかに優れる者に比べて劣っていることが推 測され, 短距離走能力に劣る者 (SF) は優れる者 (FF あるいは FS) に比べて, パワーや敏捷性が劣 っていることが推測される。SF 群が SS 群に比 べて, パワーや敏捷性において勝ったのは, 長距 離走能力に優れているといらことよりも, 短距離 走能力においても SF 群の方が SS 群に比べて勝 っていることによるものと考えられる（表 2 参 照。

以上の結果は，一般に長距離トレーニング者の 心肺機能が発達している2261 と言われているこ と, 一般集団を対象とした走パフォーマンスと前 述の体力要因との相関分析415/9)10112)17/251の結果か ら類推して妥当な結果であろらと考えられる。

従って, 選手の場合と同様, 一般の集団の場合 も特別トレーニングを行なっている訳ではない が, 概して長距離走能力に優れる者は心肺機能に 優れ, 短距離走能力に優れる者はパワーや敏捷性 に優れていると言えよう。

また, SS 群は他の群に比べて, 主として重心 の移動が伴う体カテストにおいて劣っていた（表 4 )。SS 群は, 体脂肪が多い群と考えられたこと から，この影響が移動を伴う体カテストにも反映 したと考えられる。

一方, 体力プロフィールの結果から, 走能力の 異なる 4 群の体格・体力プロフィールは異なり， それぞれ独自の身体特性を有していることが推測 される。

FS 群及び SF 群のプロフィールはそれぞれ短 距離走及び長距離走選手のものと類似していると 考えられるが，特に一般集団に㧍いて見られる
$\mathrm{SS}$ 及び FF 群のプロフィールは選手のものとは 異なっていると考学られる。すなわち, 短・長距 離走能力に劣る $\mathrm{SS}$ 群は, 量・周育は大であるが, 短距離及び長距離走の成就にそれぞれ重要と考え られるパワー・敏捷性, 心肺機能が共に劣ってお り, 両走能力に優れる FF 群の場合には前述のい ずれの能力にも優れている。FF 群に属する者が, 更にトレーニングを積むことによって，短距離あ るいは長距離を専門とする選手へと成長していく ものと推測される。

\section{V. を め}

本研究の目的は, 一般の高校生男子集団の中か ら走能力の異なる集団, すなわち, $100 \mathrm{~m}$ 及び 10 $\mathrm{km}$ の両走能力に優れている者 (FF), 劣る者(SS), $100 \mathrm{~m}$ 走能力は優れているが $10 \mathrm{~km}$ 走能力には劣 る者 (FS), その逆のケースの者 (SF) を選出し， この 4 群の身体的特性を明らかにすることであっ た。

主な結果をまとめると次の通りである。

1. SS 群は他の 3 群に比べて, 体脂肪が多く, 量・周育が大であるが, 協応性, 平衡性, 下肢の 動的筋力が劣っている。

2. 短距離走能力に優れる者 (FF 及び FS) は 劣る者 (SS 及び SF) に比べて, パワーや敏捷性 が発達しており, 長距離走能力に優れる者 $(\mathrm{FF}$ 及 びSF) は劣る者 (SS 及びFS)に比べて，心肺機能 が発達している。

3. 長育, 静的筋力, 柔軟性については, 走能 力の異なる 4 群間に差異はない。

4. 走能力の異なる 4 群は, それぞれ独自の体 カプロフィールを有しており, FS 及び SF 群の 場合は，それぞれ短距離及び長距離走選手のタイ プと類似している。

5. SS 群の場合, 他の体力要因に比べて, 量・ 周育が大であるが，心肺機能，パワー，敏捷性が 劣っており, FF 群の場合は, 長育, 量・周育の 体格面及び柔軟性に比べて, パワー, 敏捷性, 心 肺機能, 筋力が発達している。

（受付 昭和59年 4 月 11 日） 


\section{文}

1）浅川桂次，鈴木義明，鎌田喜雄(1956)：運動選手の 体勢について, 体力科学, 5(5), 165-171.

2）浅川桂次 (1956)：最大呼吸量と運動能力との関係に ついて, 体力科学, 5(5), 172-175.

3) Brožek, J., Grande, F., Anderson, J. T. and Keys, A.(1963): Densitometric alysis of body composition : review of some quantitative assumptions. Ann. N Y., 110, 113-140.

4) Costill, D. L.(1967) : The relationship between selected physiological variables and distance running performance, J. Sports Med. \& Physical Fit., 7, 61-66.

5) Costill, D. L.(1973): Fractional utilization of the aerobic capacity during distance running, Med. Sci. Sports, 5, 248-252.

6) 平田欽逸 (1976)：体格体力判定法, 大洋社, 岐皁.

7) Hirata, K.(1966): Physique and age of Tokyo Olympic Champions, J. Sports Med. and Phys. Fit. 6, 207-222.

8) 岩原信九郎(1977): 教育と心理のための推計学, 日 本文化科学者, 東京, 241-243.

9) 生田香明, 根木招郎, 栗原崇志, 播本定彦(1981)： 敏捷性・筇力・パワーから見た短距離疾走能力, 体 育学研究, 26, 111-118.

10）池上晴夫, 水本千恵子, 油座信男(1979)：8 ケ月の 激しい運動が体組成及び体力に及ぼす影響に関する 研究, 体力科学, 28, 34-46.

11) 北川 蒵, 宮下充正 (1981): 最大酸素摄取量と身体 組成から見た肥満者の呼吸循環系機能, 30(3), 131136.

12）北川 薰, 宮下充正, 山本恵三, 青年男女の身体組 成, 最大酸素摄取量および $2,400 \mathrm{~m}$ 走, 体育学研究, 21, 335-340.

13）金原勇編(1976)：陸上競技のコーチング(I), 総論・ トラック編, 大修館, 東京, 3-537.

14）川端愛義, 水町四郎, 緒方稚弘, 鈴木慎次郎編
(1969) : 体力測定と健康診断, 南江堂, 東京, 36252.

15）文部省スポーツ課内社会体育研究会編(1979)：体力 テスト——その実施と活用—, 第一法規, 東京.

16）松浦義行 (1983): 体力測定法, 朝倉書店, 東京, 159-193.

17）松浦義行 (1969): 運動能力の因子構造, 不味堂, 東 京, 120-139, 170.

18）松浦義行(1972)：行動科学に护ける因子分析法, 不 味堂, 東京, 391-414。

19）松井三雄, 水野忠文, 江橋慎四郎(1982): 体有測定 法, 体育の科学社, 42-159.

20) 長嶺晋吉(1979)スポーツとエネルギー・栄養, 現代 のスポーツ科学講座, 第 2 巻, 大修館, 東京, $259-$ 283.

21）名取礼二, 小川義雄, 横堀 栄, 木村邦彦(1970): 最新体力測定法, 同文書院, 44-282.

22）小野三嗣, 横山芳江, 倉田 博(1972) : 持久走鍜練 中高年者の体力に関する研究, 体力科学, 63-70.

23）小野三嗣(1978)：肥満を考穴直そう，不味堂, 東京, 60-65.

24) Tanner, J. M.(1964): The Physique of Olympic athlete, George Allen and Unwin Ltd, Landon.

25）田中喜代次 (1980)：中長距離走者の呼吸循㻴系機能 並びに形態特徽, 筑波大学修士論文.

26）田中喜代次(1978)：ランニングスコフ847以上の 880 ヤード・1 マイル・長距離ランナーの心肺機能, 体 育学研究, 81-90.

27）田中喜代次, 松浦義行, 浅野勝己, 菊地和夫, 出村 慎一(1979) : 中長距離ランナーの呼吸㽞環系機能及 び形態的特徵, 日本体育学会第30回大会号, 285.

28）田中信雄, 辻田純三, 堀 清記, 千賀康利, 大柣寅 之助, 山崎 武(1979)：スポーッマンの体格及び体 型に関する研究一一競技種目別による運動選手の体 格の差異について—, 体力科学, 26(3), 114-123.

29）田中信雄, 千賀康利, 黛 誠, 辻田純三, 堀 清 記(1980)大学生の体格, 体型に及ぼす身体運動の影 響, 215-232. 